\title{
Peningkatan Pemahaman Mengenai Menstruasi Melalui Penyuluhan Serta Pemeriksaan Golongan Darah Di Usia Dini
}

\author{
Sukmawati, A.Muflihunna, Zainal Abidin, Masdiana Tahir \\ Fakultas Farmasi, Universitas Muslim Indonesia \\ Email: Sukmawati.syarif@umi.ac.id
}

\begin{abstract}
Menstruation is a physiological change in a woman's body that occurs periodically and is influenced by reproductive hormones either FSHEstrogen or LH-Progesterone. In women, this usually occurs every month between teens to menopause, and lasts around 7-28 days. Knowing the characteristics of menstruation early is a very important thing to know because it is an early learning about the reproductive system and their health. Blood type is an inherited antigen on the surface of red blood cells. The two most important types of blood classification to know are the classification of $A B O$ and Rhesus (Rh factor). Blood type examination is an activity that is sometimes overlooked by the community, in this case the needs of the Blood Type are carried out for clinical purposes such as: blood transfusions, preventing transfusion complications, and for pregnant women. According to empirical data obtained in 2017 the level of understanding of menstruation and blood type in primary schools is very low. For this reason, efforts are made to provide education and information as well as checks on children from an early age as a starting point for character building in improving education and knowledge in general and specifically regarding health.
\end{abstract}

Key words : Menstruation Educated, Blood type, Children

\section{Pendahuluan}

Menstruasi, haid atau datang bulan adalah perubahan fisiologis dalam tubuh wanita yang terjadi secara berkala dan dipengaruhi oleh hormon reproduksi baik FSH-Estrogen atau LH-Progesteron. Periode ini penting dalam hal reproduksi. Pada manusia, hal ini biasanya terjadi setiap bulan antara usia remaja sampai menopause. Selain manusia, periode ini hanya terjadi pada primata-primata besar, sementara binatang-binatang menyusui lainnya mengalami siklus estrus. Pada wanita siklus menstruasi rata-rata 
terjadi sekitar 28 hari, walaupun hal ini berlaku umum, tetapi tidak semua wanita memiliki siklus menstruasi yang sama, kadang-kadang siklus terjadi setiap 21 hari hingga 30 hari. Biasanya, menstruasi rata-rata terjadi 5 hari, kadang-kadang menstruasi juga dapat terjadi sekitar 2 hari sampai 7 hari paling lama 15 hari. Jika darah keluar lebih dari 15 hari maka itu termasuk darah penyakit. Umumnya darah yang hilang akibat menstruasi adalah $10 \mathrm{~mL}$ hingga $80 \mathrm{~mL}$ per hari tetapi biasanya dengan rata-rata $35 \mathrm{~mL}$ per harinya. ${ }^{1}$

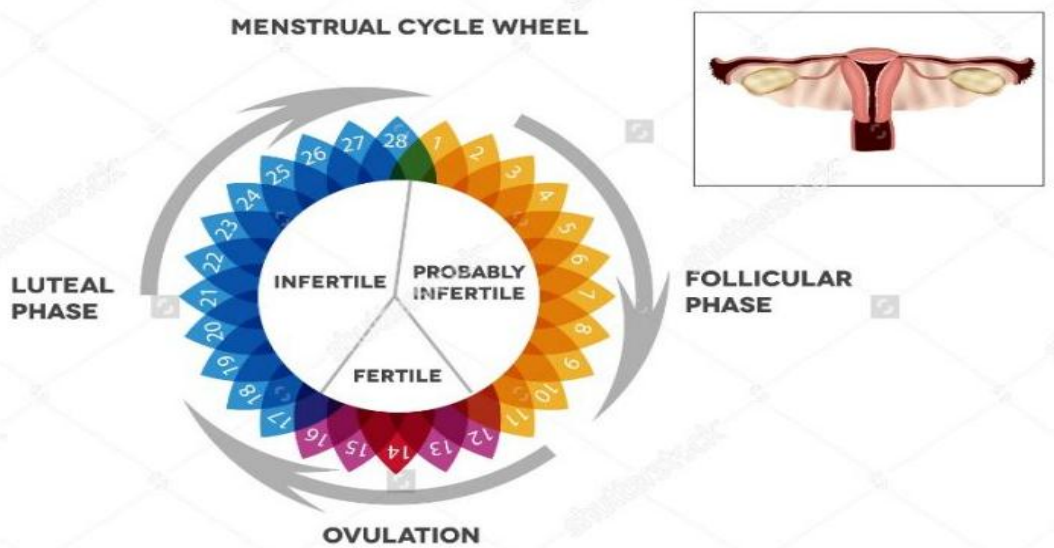

\section{Gambar 1. Proses Menstruasi (Sumber: Corwin EL, 2013)}

Fase menstruasi: Fungsi menstruasi normal merupakan hasil interaksi antara hipotalamus, hipofisis, dan ovarium dengan perubahan-perubahan terkait pada jaringan sasaran pada saluran reproduksi normal, ovarium memainkan peranan penting dalam proses ini, karena tampaknya bertanggung jawab dalam pengaturan perubahan-perubahan siklik maupun lama siklus menstruasi. Siklus endometrium terdiri dari empat fase ${ }^{2}$ yaitu:

1 Wikipedia, 2019, Menstruasi. Online.

2 Corwin EL, Patofisiologi, Jakarta, 2013 
1) Fase Menstruasi : Pada fase ini, endometrium terlepas dari dinding uterus dengan disertai pendarahan dan lapisan yang masih utuh hanya stratum basale. Rata-rata fase ini berlangsung selama lima hari (rentang 3-6 hari). Pada awal fase menstruasi kadar estrogen, progesteron, LH (Lutenizing Hormon) menurun atau pada kadar terendahnya selama siklus dan kadar FSH (Folikel Stimulating Hormon) baru mulai meningkat;

2) Fase proliferasi : Fase proliferasi merupakan periode pertumbuhan cepat yang berlangsung sejak sekitar hari ke-5 sampai hari ke-14 dari siklus haid, misalnya hari ke-10 siklus 24 hari, hari ke-15 siklus 28 hari, hari ke-18 siklus 32 hari. Permukaan endometrium secara lengkap kembali normal sekitar empat hari atau menjelang perdarahan berhenti. Dalam fase ini endometrium tumbuh menjadi setebal $\pm 3,5 \mathrm{~mm}$ atau sekitar 8-10 kali lipat dari semula, yang akan berakhir saat ovulasi. Fase proliferasi tergantung pada stimulasi estrogen yang berasal dari folikel ovarium;

3) Fase sekresi/luteal : Fase sekresi berlangsung sejak hari ovulasi sampai sekitar tiga hari sebelum periode menstruasi berikutnya. Pada akhir fase sekresi, endometrium sekretorius yang matang dengan sempurna mencapai ketebalan seperti beludru yang tebal dan halus. Endometrium menjadi kaya dengan darah dan sekresi kelenjar.

4) Iskemi/premenstrual : Implantasi atau nidasi ovum yang dibuahi terjadi sekitar 7 sampai 10 hari setelah ovulasi. Apabila tidak terjadi pembuahan dan implantasi, korpus luteum yang mensekresi estrogen dan progesteron menyusut. Seiring penyusutan kadar estrogen dan progesteron yang cepat, arteri spiral menjadi spasme, sehingga suplai darah ke endometrium fungsional terhenti dan 
terjadi nekrosis. Lapisan fungsional terpisah dari lapisan basal dan perdarahan menstruasi dimulai. ${ }^{3,4}$

\section{Metode}

Upaya peningkatan pemahaman mengenai ciri menstruasi pertama melalui Penyuluhan dan sosialisasi berupa pemberian edukasi dan contoh materi penyuluhan didampingi oleh guru dan tim pengabdi. Alat Penyuluhan dan sosialisasi mengenai menstruasi pertama: Materi penyuluhan dan seperangkat alat LCD. Alat tulis, Autoclik, Lancet, Slide. Metode Penyuluhan dan sosialisasi menstruasi pertama, yaitu: ${ }^{5}$

1) Memberikan penyuluhan tentang pengertian menstruasi

2) Proses terjadinya menstruasi

3) PMS (pre Menstruasi Syndrome)

4) Cara mengatasi PMS

5) Gangguan-gangguan menstruasi

6) Cara mengatasi nyeri menstruasi

7) Menjaga kebersihan saat menstruasi

Pemeriksaan Golongan Darah : Alat P3K dan Kit pemeriksaan golongan darah, kertas form hasil pemeriksaan, tissue, sabun cuci tangan, handscun, masker, lap kasar dan halus, kapas, Reagen Anti A, Reagen Anti B, Kapas alkohol, dilakukan pada ruang kelas yang telah dibersihkan pada tanggal 7 dan 27 Juli 2017.

Metode yang digunakan dalam pemeriksaan golongan darah sebagai berikut6: 1) Disiapkan alat dan bahan

\footnotetext{
3 Edmuson,L.D, Dysmenorrea Retrieved, 2006

${ }^{4}$ Samsuri, Hemoglobin Darah, Graha Ilmu Yogyakarta, 2009

${ }^{5}$ Ramaiah, Mengatasi Gangguan Menstruasi, Diglosia Medika, Yogyakarta, 2006

${ }^{6}$ Wikipedia. Golongan Darah, 2019.
} 
2) Diletakkan jarum pada autoclick, pastikan autoclick berada pada keadaan siap menusuk

3) Dilakukan antisepsis dengan kapas alkohol pada jari tengah/ jari manis pasien, lalu tusuk dengan autoclick

4) Tetesan darah pertama dihapus dengan tissue, lalu tetesan berikutnya ditampung diatas object glass

5) Buat sebanyak 4 tetesan pada object glass

6) Diteteskan anti - A disamping tetesan darah yang pertama, diteteskan anti - B disamping tetesan darah yang kedua, diteteskan anti - AB disamping tetesan darah yang ketiga, diteteskan anti - D disamping tetesan darah yang keempat.

7) Dihomogenkan darah dan anti - A menggunakan stick dengan arah memutar membentuk lingkaran, lalu dibersihkan stick dengan tissue, dan lakukan untuk ketiga tetesan darah dengan pereaksinya dengan cara yang sama.

8) Digoyangkan secara perlahan object glass selama kurang lebih 2 menit. Apakah hasilnya aglutinasi atau non - aglutinasi

9) Hasil dicatat.

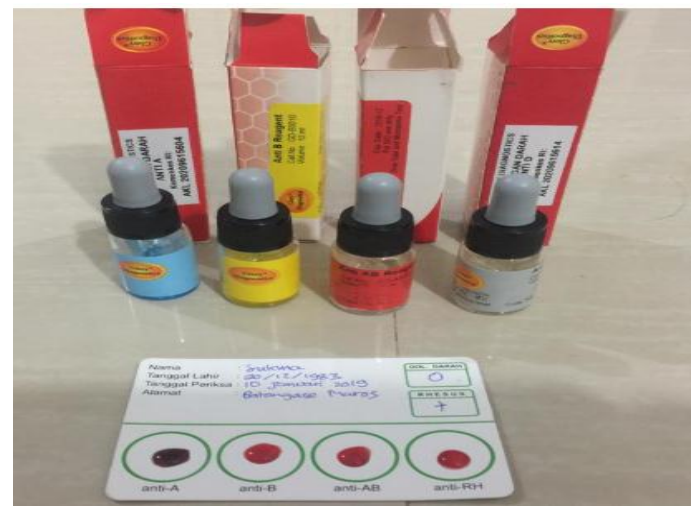

Gambar 2. Contoh hasil yang diperoleh pada pemeriksaan golongan darah (Sumber: Dokumentasi, 2017) 


\section{Hasil dan Diskusi}

Penyuluhan menstruasi dilaksanakan dengan tujuan untuk memberikan informasi yang dapat menambah pengetahuan serta memberikan edukasi bagi siswi-siswi sekolah dasar yang dikhususkan pada anak perempuan (siswi) kelas V dan VI yang merupakan usia peralihan menuju usia remaja. Berdasarkan survey yang telah dilakukan diperoleh data bahwa siswi pada usia sekolah dasar kelas V dan VI sudah ada yang mendapatkan menstruasi pertama kali. Sehingga pengetahuan tentang menstruasi perlu untuk disosialisasikan karena berhubungan dengan kesehatan reproduksi wanita dan pendidikan tentang kesehatan reproduksi khususnya menstruasi tidak tercakup di dalam kurikulum sekolah. Dan usia remaja merupakan usia yang paling rawan mengalami masalah kesehatan reproduksi seperti kehamilan usia dini, aborsi yang tidak aman, infeksi menular seksual, pelecehan seksual dan pemerkosaan. Dengan diberikan penyuluhan dan sosialisasi ini diharapkan masalah-masalah tersebut dapat dicegah.

Adapun isi materi yang berikan adalah pengertian menstruasi, bagaimana terjadinya proses menstruasi, fase-fase yang terjadi pada saat menstruasi, infeksi yang dapat terjadi pada masa mesntruasi serta memberikan edukasi cara mengatasi nyeri pada saat menstruasi, dan memberikan edukasi cara penggunaan pembalut dengan baik dan benar. Dari kegiatan penyuluhan yang telah dilakukan, diperoleh data bahwa dari siswi peserta penyuluhan terdapat 5 siswi yang telah mendapatkan menstruasi pertamanya dan pada sesi tanya jawab diketahui bahwa pengetahuan mereka tentang proses terjadinya menstruasi masih sangat kurang dan mereka masih tampak malu-malu dalam membahas organ reproduksi [11]. Informasi yang diberikan juga meliputi memberikan penyuluhan tentang pengertian menstruasi, Proses terjadinya menstruasi, PMS (pre Menstruasi 
Syndrome), Cara mengatasi PMS, Gangguan-gangguan menstruasi, Cara mengatasi nyeri menstruasi seperti:

1) Berbaring, Apabila rasa nyeri mulai muncul saat haid, maka kamu dapat merebahkan tubuh terlebih dahulu di kasur atau sofa. Biasanya, rasa nyeri timbul pada bagian punggung sehingga dengan berbaring maka rasa nyeri akan berkurang. Gunakanlah bantal di bawah lutut untuk menyangganya dan ambillah napas panjang kemudian hempaskan. Lakukanlah hal ini secara berulang sampai kamu merasa lebih nyaman.

2) Olahraga Secara Teratur, Aktivitas sederhana atau olahraga ringan akan mengurangi rasa nyeri saat haid. Olahraga ringan yang bisa dilakukan adalah berjalan, bersepeda, atau berenang. Namun, jangan memaksakan diri apabila memang kemampuannya tidak sampai. Lakukan saja olahraga yang ringan tapi dengan teratur akan lebih membantu.

3) Panas, Masukkan air hangat ke dalam botol kemudian kompreskan pada daerah perut maka rasa nyeri akan berkurang. Mengompres bagian perut akan membuatnya rileks dan otot-otot pun tidak menegang lagi.

4) Konsumsi Makanan Sehat, Berdasarkan studi, asam lemak omega 3, vitamin E, vitamin B6 dan B1, serta magnesium dapat mengurangi nyeri haid. kamu dapat mengonsumsi sayur dan buah dengan aneka macam warna, labu, ikan, dan makanan lain yang mengandung banyak protein nabati.

5) Menghindari Rokok Atau Alkohol, Merokok dan mengonsumsi alkohol akan memperburuk keadaan jadi hindarilah kebiasaan buruk tersebut.

Pemeriksaan Golongan Darah dilaksanakan dengan tujuan untuk mengetahui golongan darah yang ada dalam tubuh manusia sehingga dapat digunakan untuk memilih golongan darah yang cocok apabila orang tersebut memerlukan donor darah dan merupakan salah satu data yang diperlukan pada pengurusan administrasi. Golongan darah merupakan label khusus 
darah dari setiap individu. Pelaksanaan kegiatan pemeriksaan golongan darah ini dilakukan terhadap siswa dan siswi sekolah dasar dengan jumlah peserta \pm 50 orang.

Sistem pemeriksaan yang digunakan adalah golongan darah sistem ABO dengan menggunakan Kit pemeriksaan golongan darah, dimana darah direaksikan dengan reagen Anti A dan reagen Anti B. Pada penggolongan darah sistem ABO melibatkan dua bentuk molekul yaitu antigen dan antibodi. Antigen merupakan subtansi asing yang ada dalam tubuh, sedangkan antibodi yang bereaksi dengan antigen. Adanya antigen tipe A dan tipe B dalam sel darah merah menentukan bentuk golongan darah seseorang. Misalnya seseorang memiliki golongan darah B karena ia memiliki antigen B dalam sel darah merahnya. Reaksi antara antigen dan antibodi menyebabkan terjadinya penggumpalan darah atau aglutinasi.

Dari kegiatan pemeriksaan golongan darah yang telah dilakukan diketahui bahwa dari 50 peserta siswa dan siswi yang mau diperiksa hanya 30 orang. Terdapat 7 orang bergolongan darah A, 6 orang bergolongan darah B, 3 orang bergolongan darah $\mathrm{AB}$ dan 14 orang bergolongan darah O. Setiap peserta yang telah diperiksa diberikan kartu hasil pemeriksaan sebagai identitas telah melakukan pemeriksaan golongan darah.

Bentuk kegiatan yang dilakukan dalam peningkatan pemahaman tentang golongan darah melalui pemeriksaan termasuk prosedur awal seperti : Cuci tangan, Berikan satu tetes serum anti-A pada kaca objek sebelah kiri dan satu tetes serum anti-B sebelah kanan, Desinfeksi daerah perifer (ujung jari tangan/kaki), Tusuk daerah yang di desinfeksi dengan menggunakan lanset, Usap darah yang pertama keluar dengan kapas kering, Teteskan satu tetes darah pada kedua serum di kaca objek lalu dicampur, Goyangkan kaca dengan gerakan melingkar, Lihat adanya aglutinasi, Cuci tangan setelah prosedur dilakukan, Catat hasil prosedur dan respon pasien 

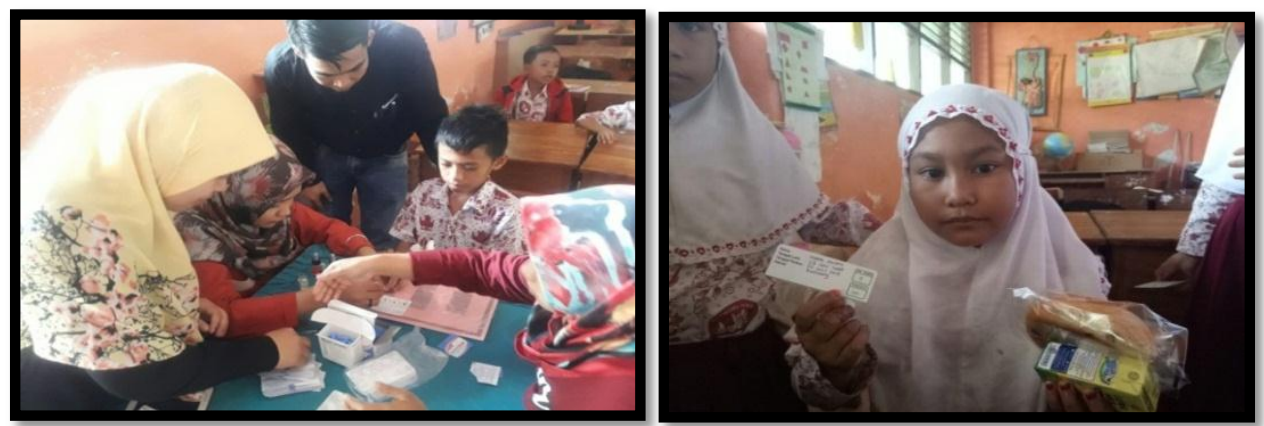

Gambar 3. Bukti Kegiatan Pemeriksaan Golongan Darah (Sumber:

Dokumentasi, 2017)

Adapun beberapa permasalahan yang timbul di antaranya adalah :

a. Masalah Menstruasi Pertama

Siswi-siswi sekolah dasar (SD) tersebut masih kurang paham tentang pentingnya informasi ini karena menstruasi pertama biasanya terjadi pada wanita usia 11-16 tahun. Setiap wanita berbeda-beda waktunya dalam mendapatkan menarce atau menstruasi pertama kali. Sekarang ini ada wanita yang mengalami menstruasi pertama kalinya pada umur 8 tahun, ada juga pada umur 9-10 tahun dan yang paling banyak adalah 60\% wanita mengalami menarce rata-rata berumur 12-15 tahun. Hal ini dipengaruhi oleh beberapa faktor, diantaranya faktor keturunan, bangsa, iklim, lingkungan, perbaikan gizi, dan latar belakang sosial ekonomi orangtua.

b. Masalah Pemeriksaan Golongan Darah

Siswa-siswi sekolah Sekolah Dasar tersebut masih kurang paham tentang pentingnya pemeriksaan golongan darah. Sehingga kami memberi fasilitas kepada anak usia dini untuk mengetahui golongan darahnya melalui program pemeriksaan golongan darah. Sejak dini pemeriksaan mengenai golongan darah untuk siswa/siswi usia dini. Di beberapa pengurusan 
administrasi, pasti akan ditanyakan apa golongan darah anda? A, B, AB dan O salah satunya adalah jawaban anda. Golongan darah merupakan label khusus darah dari setiap individu. Perbedaan golongan darah ini disebabkan karena jenis karbohidrat dan protein pada permukaan membrane sel darah merah yang berbeda. Penentuan golongan darah tergantung dari jumlah zat (antigen) yang terkantung dalam sel darah merah.

Evaluasi kegiatan bertujuan untuk memastikan bahwa kegiatan yang telah kami lakukan bersama-sama dapat dipahami dan diterapkan dalam kehidupan sehari-hari.

Beberapa yang telah dilakukan adalah:

1) melakukan pengumpulan data awal tentang penyuluhan menstruasi yang dilakukan melalui brosur yang dibagikan

2) mempelajari tujuan penyuluhan melalui permasalahn yang dihadapi siswi saat penyuluhan

3) membagikan kartu identitas golongan darah lengkap dengan hasil testnya

4) membagikan pamplet tentang golongan-golongan darah $\mathrm{A}, \mathrm{B}, \mathrm{AB}$, dan $\mathrm{O}$ serta rhesus $(+)$ atau $(-)$

\section{Simpulan}

Berdasarkan hasil pelaksanaan kegiatan yang telah dilaksanakan dapat ditarik beberapa kesimpulan sebagai berikut:

1) Pengetahuan dan pemahaman para guru dan murid SD tentang upaya peningkatan informasi yang dapat menambah pengetahuan serta memberikan edukasi bagi siswi-siswi sekolah dasar telah meningkat setelah mengikuti sosialisasi dan penyuluhan 
2) Pentingnya mengenal ciri menstruasi pertama merupakan hal yang sangat penting untuk diketahui karena merupakan pembelajaran awal mengenai sistem reproduksi dan kesehatan secara dini.

3) Mengetahui golongan darah sejak dini akan membantu kebutuhan administrasi kedepannya, baik untuk kesehatan maupun pendidikan

\section{Referensi}

Anurogo, D. (2002). Segala Sesuatu Tentang Nyeri Haid. Retrieved January 3, 2009, from http://www.kabarindonesia.com.http://www.emedicine.com.

Corwin, E.J. (2003). Patofisiologi. Jakarta : EGC.

Dawkins, R. (2006). Gangguan Kasehatan Pada Setiap Periode Kehidupan Wanita, majalah Smart Living. Edisi 3 : 10-14.

Edmuson, L. D. (2006). Dysmenorrea. Retrieved January 3, from

Fitria, A. 2007. Panduan Lengkap Kesehatan Wanita. Yogyakarta : Gala Ilmu Semesta.

Hurlock, E. B. (2005). Psikologi Perkembangan Suatu Pendekatan Sepanjang Rentang Kehidupan Edisi 5. Jakarta : Erlangga

Misaroh, S. \& Proverawati, A. (2009). Menarche.yogyakarta : Nuha Medika.

Ramaiah, S. 2006. Mengatasi Gangguan Menstruasi. Yogyakarta : Diglosia Medika.

Samsuri. (2004)Hemoglobin Darah. Graha Ilmu: Yogyakarta.

Soetjiningsih. (2004). Tumbuh Kembang Remaja dan Permasalahannya. Jakarta: Sagung Seto.

Qinntun. (2008). Konsep Dismenorhea. Retreivet January 3, 2009, from http://www.artikelkesehatan.com. Edisi Ketiga Jilid 2. Media Aesculapius Fakultas Kedokteran UI.

Wikipedia.

Golongan

darah. http://id.m.wikipedia.org/wiki/Golongan_darah. Diakses, 10 Oktober 2017

Wikipedia.

Menstruasi. https://id.wikipedia.org/wiki/Menstruasi\#: :text=Menstruasi $\% 2 \mathrm{C} \% 2$ 0haid\%20atau\%20datang\%20bulan,antara\%20usia\%20remaja\%20sa mpai\%20menopause. Diakses, 10 Oktober 2017. 